\title{
DECISION SUPPORT OF CONTRACT EMPLOYEE PERFORMANCE ASSESSMENT USING SAW METHOD AT PT. AEROFOOD ACS
}

\author{
Fathur Rahman ${ }^{*}$ ); Naf'a Syarifa ${ }^{2 *}$; Hendri3 ${ }^{3}$ Hafifah Bella Novitasari4; Windu Gata ${ }^{5}$ \\ 1,5Program Studi Ilmu Komputer \\ Universitas Nusa Mandiri \\ www.nusamandiri.ac.id \\ 14002351@nusamandiri.ac.id ${ }^{1 *}$, windu@nusamandiri.ac.id ${ }^{5}$ \\ 2Program Studi Sistem Informasi \\ Universitas Bina Sarana Informatika, Indonesia \\ www.bsi.ac.id \\ 11190313@nusamandiri.ac.id ${ }^{2 *}$, hendri.hed@nusamandiri.ac.id ${ }^{3}$ \\ ${ }^{4}$ Program Studi Sistem Informasi \\ STMIK Bani Saleh \\ www.stmik.banisaleh.ac.id \\ hafifahbela@stmik-banisaleh.ac.id ${ }^{4}$ \\ (*) Corresponding Author
}

\begin{abstract}
Human resource management of a company greatly influences many aspects that determine the success of the company's performance. If HR can be well organized, it is hoped that the company can carry out all its business processes properly. Because of this, PT. Aerofood ACS, which has many contract employees, needs an employee performance appraisal in determining contract extensions. The role of decision support systems is needed to increase the efficiency of decision-making. In this case, it helps the management achieve the objectives of the performance appraisal of contract employees through the parameters that have been determined by the company, including Discipline, Integrity, Achievement Orientation, Continuous Learning, Continuous Improvement, Quality Orientation, Customer Service Orientation, and Teamwork. To find a solution solving this problem, the method used in the Decision-Making System is the Simple Additive Weighting (SAW) method. All parameters stated have an important influence in determining the best alternative decision in determining the employee contract extension.
\end{abstract}

Keywords: decision support; employee performance assessment; simple additive weighting.

Abstrak- Pengelolaan SDM dari suatu perusahaan sangat mempengaruhi banyak aspek penentu keberhasilan kinerja perusahaan tersebut. Jika SDM dapat di organisir dengan baik, maka diharapkan perusahaan dapat menjalankan semua proses bisnisnya dengan baik. Oleh karena hal tersebut, PT.
Aerofood ACS yang memiliki banyak karyawan kontrak, perlu adanya penilaian kinerja karyawan dalam menentukan perpanjangan kontrak. Peran sistem pendukung keputusan sangat dibutuhkan guna meningkatkan efisiensi pengambilan keputusan. Dalam hal ini membantu pihak manajemen dalam mencapai tujuan dari penilaian kinerja karyawan kontrak melalui parameterparameter yang sudah ditentukan oleh pihak perusahaan tersebut, diantaranya Discipline, Integrity, Achievement Orientation, Continnous Learning, Continunous Improvement, Quality Orientation, Customer Service Orientation, dan Teamwork. Untuk mencari solusi dalam menyelesaikan masalah tersebut, metode dalam Sistem Pengambilan Keputusan yang digunakan yaitu dengan metode Simple Additive Weighting (SAW). Semua parameter yang dinyatakan mempunyai pengaruh penting dalam penetapan alternatif keputusan terbaik dalam menentukan perpanjangan kontrak karyawan.

Kata Kunci: pendukung keputusan; penilaian kinerja karyawan; simple additive weighting.

\section{INTRODUCTION}

Employees are one of the most important human resources in a company. One of the efforts in carrying out the success of the company's performance is a performance appraisal. According to (Surajiyo et al, 2020) human resources is one of the strategic areas of the organization. One way to obtain quality Human Resources can be through employee performance appraisal efforts. In 
everyday life, a person often faces choices to make decisions. The ability to make quick and wise decisions will be the key to success in global competition.

Recommendations to determine decision making is one of the matters relating to semistructured issues (Nofriansyah \& Defit, 2017). This is because employees are the company's most important asset in maintaining its survival, development, competitiveness, and profitability (Hertyana, 2018). According to (Thamrin, 2019) it is necessary to make plan Human Resources to maintain quality in increasingly fierce competition between employees, and the decision to extend the contract becomes increasingly difficult, especially if there are only a few employees with slight differences in abilities. Unfair decisions can have a negative impact on the company. This will reduce the level of performance of company employees. Therefore, it is necessary to make the right and wise decisions to determine the promotion of employees. In general, contract extensions are based on recommendations from superiors or related work units, based on Discipline, Integrity, Achievement Orientation, Continuous Learning, Continuous Improvement, Quality Orientation, Customer
Service Orientation, Teamwork in carrying out their duties.

Therefore, it is necessary to process employee evaluation data processing to make it easier for superiors to make decisions regarding employee contract extensions more easily. Currently the company still uses MS Excel to process employee evaluation data, so given the large number of employees, input errors are very likely to occur and require a relatively long time. Other than that,

information about changing staff formations is often confusing. The method used to determine the extension of the employee contract using Simple Additive Weighting (SAW). If this method is a weighted calculation method, or provides several standard methods, each value from this standard has a weight, then the total weight will be the final decision (Wati \& Sadikin, 2019). This method is the most widely used method in dealing with Multiple Attribute Decision Making (MADM) situations (Christin \& Informatika, 2015). Problem solving using the Simple Additive Weighting (SAW) method to describe the weights that meet the appropriate contract extension criteria (using the manual method), so it takes a lot of time to determine employee weights.

Table 1. Study of Literature

\begin{tabular}{|c|c|c|}
\hline Research Problem & & Literature Support \\
\hline \multirow[t]{3}{*}{ Problem Analysis I } & \multirow[t]{3}{*}{$\begin{array}{l}\text { Calculation of Ms. excel takes a } \\
\text { long time to determine employee } \\
\text { performance. }\end{array}$} & $\begin{array}{l}\text { The manual assessment process is very likely } \\
\text { to make errors in calculating each criterion, } \\
\text { and it takes a long time in the calculation } \\
\text { process (Ades, et al 2015) }\end{array}$ \\
\hline & & $\begin{array}{l}\text { Often manual processes have difficulty in } \\
\text { employee performance being slow and } \\
\text { inaccurate (Yoga \& Hendra, 2015) }\end{array}$ \\
\hline & & $\begin{array}{l}\text { The number of employees with manual } \\
\text { processes takes a long time and often } \\
\text { employee performance appraisals are carried } \\
\text { out not objectively (Siti \& Widania, 2019) }\end{array}$ \\
\hline Problem Analysis II & Gradual selection & $\begin{array}{l}\text { Staged selection such as filing, oral \& written } \\
\text { tests and interviews looks less precise and } \\
\text { takes a long time (Mallu, 2015) }\end{array}$ \\
\hline
\end{tabular}

From the results of the research literature in Table 1, it is explained that currently the problems in performance appraisal include the absence of an easier calculation to calculate the data for each criterion. The data is useful for determining the weighting value within a certain period of time with a subjective assessment. Based on previous research to solve this problem, several techniques are used in determining employee contract extensions. The results showed that the gap analyst explained the Simple Additive Weighting method of decision support model that was able to provide the best recommended solution with the criteria and weights determined at the beginning before the calculation.

The purposes of scientific writing are 1) To provide ideas on how to use the Simple Additive Weighting (SAW) method to determine a decision support system for evaluating contract employee performance. 2) Design a decision-making system that can more easily determine employee contract extensions. 3) Support the smooth performance evaluation system and make it easier to determine the contract extension data to be determined. 4) Help determine data related to processing and 
determine whether it meets contract employee renewal requirements.

\section{MATERIALS AND METHODS}

\section{Simple Additive Weight (SAW) Method}

According to (Nofriansyah, 2015) suggests that the Simple Additive Weighting method is often also known as the weighted addition method. The basic concept of Simple Additive Weighting is to find the weighted sum of the performance ratings on each alternative on all attributes. The Simple Additive Weighting method requires the process of normalizing the decision matrix $(\mathrm{X})$ to a scale that can be compared with all existing alternative ratings.

The steps for solving a problem using the Simple Additive Weighting method are:

1. Determine the alternative, namely Ai.

2. Determine the criteria that will be used as a reference in making decisions, namely $\mathrm{Cj}$.

3. Determine the suitability rating of each alternative on each criterion.

4. Determine the preference weight or importance level (W) of each criterion.

$\mathrm{W}=\left[\mathrm{W}_{1}, \mathrm{~W}_{2}, \mathrm{~W}_{3}, \ldots \mathrm{W}_{\mathrm{j}}\right]$

5. Create a match rating table for each alternative on each criterion.

6. Make a decision matrix (X) which is formed from the suitability rating table of each alternative on each criterion. The value of $\mathrm{X}$ for each alternative $(\mathrm{Ai})$ on each criterion $(\mathrm{Cj})$ that has been determined, where $\mathrm{i}=1,2, \ldots \mathrm{m}$ and $\mathrm{j}=$ $1,2, \ldots n$.

$\mathrm{X}=\left[\begin{array}{ccc}\mathrm{X}_{11} \mathrm{X}_{12} & \ldots & \mathrm{X}_{1 \mathrm{j}} \\ \cdot & & \cdot \\ \cdot & \cdot & \cdot \\ \mathrm{X}_{\mathrm{i} 1} \mathrm{X}_{\mathrm{i} 2} & \ldots & \mathrm{X}_{\mathrm{ij}}\end{array}\right]$

7. Normalize the decision matrix by calculating the value of the normalized performance rating (rij) from the alternative $\mathrm{Ai}$ on the $\mathrm{Cj}$ criteria.

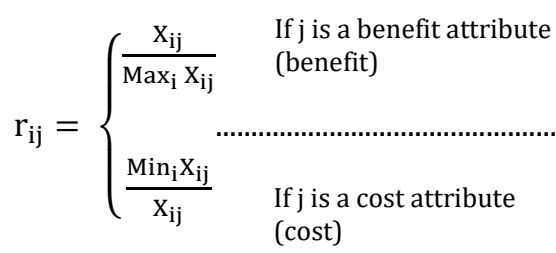

Information :

\begin{tabular}{|c|c|}
\hline rij & $\begin{array}{l}=\text { Normalized performance rating } \\
\text { value }\end{array}$ \\
\hline Max Xij & $=$ Maximum value of each criterion \\
\hline Min X & $=$ Minimum value of each criterion \\
\hline Xij & $\begin{array}{l}=\text { The attribute value of each } \\
\text { criterion }\end{array}$ \\
\hline & $=$ If the biggest value is the best \\
\hline
\end{tabular}

8. The results of the normalized performance rating (rij) form a normalized matrix (R)

$$
\mathrm{R}=\left[\begin{array}{cccc}
\mathrm{X}_{11} & \mathrm{X}_{12} & \ldots & \mathrm{X}_{1 \mathrm{j}} \\
\cdot & & \cdot \\
\cdot & \cdot & \cdot \\
\mathrm{X}_{\mathrm{i} 1} & \mathrm{X}_{\mathrm{i} 2} & \ldots & \mathrm{X}_{\mathrm{ij}}
\end{array}\right]
$$

9. The final result of preference (Vi) is obtained from the addition and multiplication of normalized matrix row elements (R) with preference weights (W) corresponding to matrix column elements $(\mathrm{W})$

$V_{i}=\sum_{j=1}^{n} W_{j} r_{i j}$

Information :

$\mathrm{Vi}=$ Rank for each alternative

$\mathrm{Wj}$ = Weighted value of each criterion

$\mathrm{r}_{\mathrm{ij}}=$ Normalized work rating value

A larger $\mathrm{Vi}$ value indicates that alternative $\mathrm{Ai}$ is preferred.

The steps taken from decision support for performance appraisal decisions with predetermined criteria are as follows:

1. Determine each of the criteria

Table 2. Criteria Terms

\begin{tabular}{ll}
\hline Code & \multicolumn{1}{c}{ Criteria } \\
\hline C1 & Discipline \\
\hline C2 & Integrity \\
\hline C3 & Achievement Orientation \\
\hline C4 & Continunous Learning \\
\hline C5 & Continunous Improvement \\
\hline C6 & Quality Orientation \\
\hline C8 & Team Work \\
\hline
\end{tabular}

Source : (Aerofood ACS, 2020)

From the provisions of the criteria in Table 2, each has the following explanation:

C1 $=$ Be punctual in using work time both at work and at rest, including other activities determined by the company and using work clothes in accordance with the provisions that have been set.

C2 = Uphold integrity and behave consistently according to company values. Such as: acting honestly, keeping promises, not KKN, refusing bribes/gratuities, not taking advantage of vendors, etc.

C3 = Work seriously to the maximum and consistently in achieving work targets / exceeding customer / superior expectations.

$\mathrm{C} 4=$ Always actively learning new things to increase competence and support performance achievement, such as actively participating in training/seminar activities, reading books, learning from superiors, trial \& error, etc. 
C5 = Always come up with new ideas that are creative and active in improving the work system in the work area to make it more effective and efficient. C6 = Always comply with SOPs and do not repeat mistakes in work and ensure work results are in accordance with established standards or customer expectations both internally and externally (including superiors).

C7 = Identify, understand and provide products \& services according to the needs / desires of customers both internally / externally (including superiors) and evaluate their satisfaction with the products / services provided.

C8 = Able to work together in a team such as: helping and supporting co-workers, not prioritizing personal interests, respecting the opinions of others who are different, participating in providing suggestions/ideas for the team, appreciating colleagues who excel, sharing important information with the team, etc.

2. Give a weight value to the criteria

Table 3. Value Determination

\begin{tabular}{clc}
\hline Code & \multicolumn{1}{c}{ Criteria } & Weight \\
\hline C1 & Discipline & 15 \\
\hline C2 & Integrity & 20 \\
\hline C3 & Achievement Orientation & 10 \\
\hline C4 & Continunous Learning & 10 \\
\hline C5 & Continunous Improvement & 10 \\
\hline C6 & Quality Orientation & 15 \\
\hline C7 & Customer Service & 10 \\
& Orientation & \\
\hline C8 & Team Work & 10 \\
\hline
\end{tabular}

Source : (Abadi \& Latifah, 2016)

There is a weighted value given for each criterion in Table 3, with the determination of values varying from the highest weight $\mathrm{C} 1$ to the lowest weight C3, C4, C5, C7 and C8.

3. Weighting on each criterion

Table 4. Criteria Weighting (C1)

\begin{tabular}{clc}
\hline $\begin{array}{c}\text { Discipline } \\
\text { Assessment }\end{array}$ & Information & Score \\
\hline $1-20$ & Very low & 1 \\
\hline $21-40$ & Low & 2 \\
\hline $41-60$ & Medium & 3 \\
\hline $61-80$ & High & 4 \\
\hline $81-100$ & Very high & 5 \\
\hline
\end{tabular}

Source : (Abadi \& Latifah, 2016)

\begin{tabular}{clc}
\hline $\begin{array}{c}\text { Integrity } \\
\text { Assessment }\end{array}$ & Information & Score \\
\hline $1-20$ & Very low & 1 \\
\hline $21-40$ & Low & 2 \\
\hline $41-60$ & Medium & 3 \\
\hline $61-80$ & High & 4 \\
\hline $81-100$ & Very high & 5 \\
\hline
\end{tabular}

Source : (Abadi \& Latifah, 2016)

Table 6. Criteria Weighting (C3)

\begin{tabular}{clc}
\hline $\begin{array}{c}\text { Achievement } \\
\text { Orientation } \\
\text { Assessment }\end{array}$ & Information & Score \\
\hline $1-20$ & Very low & 1 \\
\hline $21-40$ & Low & 2 \\
\hline $41-60$ & Medium & 3 \\
\hline $61-80$ & High & 4 \\
\hline $81-100$ & Very high & 5 \\
\hline
\end{tabular}

Source : (Abadi \& Latifah, 2016)

Table 7. Criteria Weighting (C4)

\begin{tabular}{clc}
\hline $\begin{array}{c}\text { Continunous } \\
\text { Learning } \\
\text { Assessment }\end{array}$ & Information & Score \\
\hline $1-20$ & Very low & 1 \\
\hline $21-40$ & Low & 2 \\
\hline $41-60$ & Medium & 3 \\
\hline $61-80$ & High & 4 \\
\hline $81-100$ & Very high & 5 \\
\hline
\end{tabular}

Source : (Abadi \& Latifah, 2016)

Table 8. Criteria Weighting (C5)

\begin{tabular}{clc}
\hline $\begin{array}{c}\text { Continunous } \\
\text { Improvement } \\
\text { Assessment }\end{array}$ & Information & Score \\
\hline $1-20$ & Very low & 1 \\
\hline $21-40$ & Low & 2 \\
\hline $41-60$ & Medium & 3 \\
\hline $61-80$ & High & 4 \\
\hline $81-100$ & Very high & 5 \\
\hline
\end{tabular}

Source : (Abadi \& Latifah, 2016)

Table 9. Criteria Weighting (C6)

\begin{tabular}{clc}
\hline $\begin{array}{c}\text { Quality } \\
\text { Orientation } \\
\text { Assessment }\end{array}$ & Information & Score \\
\hline $1-20$ & Very low & 1 \\
\hline $21-40$ & Low & 2 \\
\hline $41-60$ & Medium & 3 \\
\hline $61-80$ & High & 4 \\
\hline $81-100$ & Very high & 5 \\
\hline
\end{tabular}

Source : (Abadi \& Latifah, 2016)

Table 10. Criteria Weighting (C7) 


\begin{tabular}{clc}
\hline $\begin{array}{c}\text { Customer } \\
\text { Service } \\
\text { Orientation } \\
\text { Assessment }\end{array}$ & Information & Score \\
\hline $1-20$ & Very low & 1 \\
\hline $21-40$ & Low & 2 \\
\hline $41-60$ & Medium & 3 \\
\hline $61-80$ & High & 4 \\
\hline $81-100$ & Very high & 5 \\
\hline
\end{tabular}

Source : (Abadi \& Latifah, 2016)

Table 11. Criteria Weighting (C8)

\begin{tabular}{clc}
\hline $\begin{array}{c}\text { Team Work } \\
\text { Assessment }\end{array}$ & Information & Score \\
\hline $1-20$ & Very low & 1 \\
\hline $21-40$ & Low & 2 \\
\hline $41-60$ & Medium & 3 \\
\hline $61-80$ & High & 4 \\
\hline $81-100$ & Very high & 5 \\
\hline
\end{tabular}

Source : (Abadi \& Latifah, 2016)

Based on the weighting of the criteria in Table 4-11, of course it will affect the results of the calculations in criteria $\mathrm{C} 1$ to $\mathrm{C8}$. There is a performance assessment based on the criteria above, the company matches the value according to the highest length is 5 and the lowest is 1.

\section{RESULTS AND DISCUSSION}

One of the solutions to the problem of evaluating employee performance, it requires criteria and weights in performing calculations so as to obtain the best alternative results using the Simple Additive Weighting (SAW) method as follows :

1. Value of each employee's suitability rating

Table 12. Suitability Rating

\begin{tabular}{|c|c|c|c|c|c|c|c|c|c|}
\hline \multirow{2}{*}{ No. } & \multirow{2}{*}{$\begin{array}{c}\text { Employee } \\
\text { Code }\end{array}$} & \multicolumn{8}{|c|}{ Employee Assessment Results } \\
\hline & & C1 & $\mathrm{C} 2$ & $\mathrm{C} 3$ & $\mathrm{C} 4$ & $\mathrm{C} 5$ & C6 & $\mathrm{C} 7$ & $\mathrm{C} 8$ \\
\hline 1 & $\mathrm{~A} 1$ & 4 & 4 & 4 & 4 & 4 & 4 & 4 & 5 \\
\hline 2 & $\mathrm{~A} 2$ & 4 & 4 & 4 & 4 & 4 & 4 & 5 & 4 \\
\hline 3 & A3 & 5 & 5 & 5 & 4 & 5 & 5 & 5 & 5 \\
\hline 4 & A4 & 4 & 5 & 4 & 4 & 5 & 5 & 5 & 4 \\
\hline 5 & A5 & 4 & 4 & 4 & 5 & 4 & 5 & 5 & 5 \\
\hline 6 & A6 & 4 & 5 & 4 & 5 & 5 & 5 & 5 & 5 \\
\hline 7 & A7 & 5 & 5 & 5 & 4 & 5 & 4 & 5 & 5 \\
\hline 8 & A8 & 4 & 5 & 5 & 4 & 4 & 4 & 4 & 4 \\
\hline 9 & A9 & 5 & 5 & 5 & 5 & 4 & 5 & 4 & 5 \\
\hline 10 & $\mathrm{~A} 10$ & 4 & 4 & 4 & 4 & 4 & 4 & 4 & 4 \\
\hline 11 & A11 & 5 & 4 & 4 & 4 & 5 & 5 & 5 & 5 \\
\hline 12 & A12 & 5 & 5 & 5 & 5 & 4 & 5 & 5 & 5 \\
\hline 13 & A13 & 4 & 4 & 5 & 4 & 4 & 4 & 5 & 4 \\
\hline 14 & A14 & 5 & 5 & 4 & 4 & 4 & 4 & 4 & 4 \\
\hline 15 & A15 & 4 & 4 & 5 & 5 & 4 & 4 & 4 & 4 \\
\hline
\end{tabular}

Based on the results in Table 12 . between A1A15 have different suitability rating values, this depends on each employee's value on each of the existing criteria.
Make a decision matrix formed from the table of the Suitability Rating of each alternative on each criterion that has been determined with the decision matrix $(\mathrm{X})$ as follows:

$$
X=\left\{\begin{array}{llllllll}
4 & 4 & 4 & 4 & 4 & 4 & 4 & 5 \\
4 & 4 & 4 & 4 & 4 & 4 & 5 & 4 \\
5 & 5 & 5 & 4 & 5 & 5 & 5 & 5 \\
4 & 5 & 4 & 4 & 5 & 5 & 5 & 4 \\
4 & 4 & 4 & 5 & 4 & 5 & 5 & 5 \\
4 & 5 & 4 & 5 & 5 & 5 & 5 & 5 \\
5 & 5 & 5 & 4 & 5 & 4 & 5 & 5 \\
4 & 5 & 5 & 4 & 4 & 4 & 4 & 4 \\
5 & 5 & 5 & 5 & 4 & 5 & 4 & 5 \\
4 & 4 & 4 & 4 & 4 & 4 & 4 & 4 \\
5 & 4 & 4 & 4 & 5 & 5 & 4 & 5 \\
5 & 5 & 5 & 5 & 4 & 5 & 5 & 5 \\
4 & 4 & 5 & 4 & 4 & 4 & 5 & 4 \\
5 & 5 & 4 & 4 & 4 & 4 & 4 & 4 \\
4 & 4 & 5 & 5 & 4 & 4 & 4 & 4
\end{array}\right\}
$$

3. Normalization of Decision Matrix (X)

From the decision matrix equation $\mathrm{X}$ obtained Normalization matrix $\mathrm{R}$ as follows:

$$
\mathrm{R}=\left\{\begin{array}{cccccccc}
0.8 & 0.8 & 0.8 & 0.8 & 0.8 & 0.8 & 0.8 & 1 \\
0.8 & 0.8 & 0.8 & 0.8 & 0.8 & 0.8 & 1 & 0.8 \\
1 & 1 & 1 & 0.8 & 1 & 1 & 1 & 1 \\
0.8 & 1 & 0.8 & 0.8 & 1 & 1 & 1 & 0.8 \\
0.8 & 0.8 & 0.8 & 1 & 0.8 & 1 & 1 & 1 \\
0.8 & 1 & 0.8 & 1 & 1 & 1 & 1 & 1 \\
1 & 1 & 1 & 0.8 & 1 & 0.8 & 1 & 1 \\
0.8 & 1 & 1 & 0.8 & 0.8 & 0.8 & 0.8 & 0.8 \\
1 & 1 & 1 & 1 & 0.8 & 1 & 0.8 & 1 \\
0.8 & 0.8 & 0.8 & 0.8 & 0.8 & 0.8 & 0.8 & 0.8 \\
1 & 0.8 & 0.8 & 0.8 & 1 & 1 & 0.8 & 1 \\
1 & 1 & 1 & 1 & 0.8 & 1 & 1 & 1 \\
0.8 & 0.8 & 1 & 0.8 & 0.8 & 0.8 & 1 & 0.8 \\
1 & 1 & 0.8 & 0.8 & 0.8 & 0.8 & 0.8 & 0.8 \\
0.8 & 0.8 & 1 & 1 & 0.8 & 0.8 & 0.8 & 0.8
\end{array}\right\}
$$

4. Calculation Results

Table 13. Calculation Results

\begin{tabular}{clc}
\hline No. & \multicolumn{1}{c}{ Employee Name } & Test Result \\
\hline V1 & Khairunnisa Prawidya & 8.2 \\
\hline V2 & Ahmad Syafei Zubaedi & 8.2 \\
\hline V3 & Taryono & 9.8 \\
\hline V4 & Fathur Rahman & 9.1 \\
\hline V5 & Khodirin & 8.9 \\
\hline V6 & Muhamad Rizki Maulana & 9.5 \\
\hline V7 & Mujibur Rohman Efendi & 9.5 \\
\hline V8 & Rivan Arbianto & 8.6 \\
\hline V9 & Yuliana & 9.6 \\
\hline V10 & Arman & 8 \\
\hline V11 & Qoisul Kurnain & 9 \\
\hline V12 & Vida Lerian & 9.8 \\
\hline V13 & Wahyu Gunawan & 8.4 \\
\hline V14 & Eli Wijaya & 8.7 \\
\hline V15 & Ukar Irwansyah & 8.4 \\
\hline
\end{tabular}

2. Decision Matrix 
Based on the results of the ranking process in Table 13, the largest value is obtained in V3 and V12, so that the alternative V3 on behalf of Taryono and V12 on behalf of Vida Lerian is the chosen alternative as the best alternative for contract extension and is eligible as the first and second employee at PT Aerofood ACS.

Table 14. Best Contract Extension Ranking

\begin{tabular}{clcc}
\hline No & Employee Name & Code & Result \\
\hline 1 & Taryono & V3 & 9.8 \\
\hline 2 & Vida Lerian & V12 & 9.8 \\
\hline 3 & Yuliana & V9 & 9.6 \\
\hline 4 & Muhamad Rizki Maulana & V6 & 9.5 \\
\hline 5 & Mujibur Rohman Efendi & V7 & 9.5 \\
\hline 6 & Fathur Rahman & V4 & 9.1 \\
\hline
\end{tabular}

From the results of the calculations in Table 14, apart from Taryono and Vida Lerian who are the best alternatives, it can also be determined that 6 (six) employees have the best value for the recommendation for extension of contract employees.

\section{CONCLUSION}

The Simple Additive Weighting (SAW) method of calculating the employee performance appraisal process by assigning a value to each weighting criterion with reference to Discipline, Integrity, Achievement Orientation, Continnous Learning, Continunous Improvement, Quality Orientation, Customer Service Orientation, Teamwork formed a compatibility rating with normalization and ranking to produce the highest and lowest scores, the best score is 9.8 on behalf of Taryono and the lowest score is 8 on behalf of Arman. Thus, getting a recommendation for an extension of a contract employee is not only seen through the criteria for discipline at work, but also based on several criteria.

\section{REFERENCE}

Abadi, Satria \& Latifah, Febriani. 2016. Decision Support System Penilaian Kinerja Karyawan Pada Perusahaan Menggunakan Metode Simple Additive Weighting. Jurnal TAM, Vol : 6, pp. 3743

Ades, et al. 2015. Sistem Pendukung Keputusan
Penilaian Kinerja Menggunakan Metode SAW di Universitas Muhammadiyah Purwokerto. JUITA, Vol : III No.4. pp. 193-200

Agustin, YH \& Kurniawan, Hendra. 2015. Sistem Pendukung Keputusan Penilaian Kinerja Dosen Menggunakan Metode Weighted Product (Studi Kasus : STMIK Pontianak). Seminar Nasional Informatik

Aisyah, Siti \& Purba, Windania. 2019. Aplikasi Sistem Pendukung Keputuasan Penilaian Kinerja Karyawan Menggunakan Metode Profile Matching. Jurnal Mahajana Informasi. Vol : 4 No. 2

Christin, H. De Djamain \& Informatika, J.T. 2015. Sistem Pendukung Keputusan Penerimaan Pegawai Baru PT. PLN (Persero) Kantor Pusat dengan Menggunanakn Metode Simple Additive Weighting (SAW). Jurnal Teknologi dan Informasi, 5(1), 39-47.

Hertyana, H. (2018). Sistem pendukung keputusan penentuan karyawan terbaik menggunakan metode topsis. Jurnal Ilmu Pengetahuan dan Teknologi Komputer 4(1).

Mallu, Satriawaty. 2015. Sistem Pendukung Keputusan Penentuan Karyawan Kontrak Menjadi Karyawan Tetap Menggunakan Metode TOPSIS. Jurnal Informasi Terapan. Vol : 1 No. 2

Nofriansyah, Dicky. 2015. Konsep Data Mining VS Sistem Pendukung Keputusan. Yogyakarta: Deepublish Publisher.

Nofriansyah, Dicky \& Defit, Sarjon. 2017. Multi Criteria Decision Making (MCDM) pada Sistem Pendukung Keputusan. Yogyakarta : Deepublish Publisher.

Surajiyo et al. (2020). Penelitian Sumber Daya Manusia. Yogyakarta: Deepublish Publisher.

Thamrin HM. 2019. Perencanaan Sumber Daya Manusia. Yogyakarta: Deepublish Publisher.

Wati, Y. A., \& Sadikin. 2019. Keputusan Prioritas Perbaikan MOLD Menggunakan Metode SAW (Simple Additive Weighting). Jurnal Ilmu Teknik dan Komputer, 3(1), 1-10. 